\title{
Differences in the Association Among the Vitamin D Concentration, Dietary Macronutrient Consumption, and Metabolic Syndrome Depending on Pre- and Postmenopausal Status in Korean Women: A Cross-Sectional Study [Corrigendum]
}

Chun H, Kim GD, Doo M. Diabetes Metab Syndr Obes. 2020;13:3601-3609.

Page 3601, Results, third and fourth sentence, the text "Among the postmenopausal women with high consumption of dietary carbohydrate, the adjusted odds ratios (ORs) [95\% confidence intervals (95\% CIs)] of MetS among participants with $25(\mathrm{OH})$ $\mathrm{D}$ deficiency increased 1.380 -fold $(95 \% \mathrm{CI}=1.086-1.753)$ using the $25(\mathrm{OH}) \mathrm{D}$-sufficient group as a reference. In contrast, the participants with $25(\mathrm{OH}) \mathrm{D}$ deficiency showed an increased risk of MetS [OR $(95 \% \mathrm{CI})=1.313(1.041-1.655)]$ with low- fat consumption" should read "Among the postmenopausal women with high consumption of dietary carbohydrate, the adjusted odds ratios (ORs) [95\% confidence intervals (95\% CIs)] of MetS among participants with 25(OH)D deficiency increased 1.261-fold (95\% CI $=1.013-1.570)$ using the 25 $(\mathrm{OH}) \mathrm{D}$-sufficient group as a reference. In contrast, the participants with $25(\mathrm{OH}) \mathrm{D}$ deficiency showed an increased risk of MetS [OR $(95 \%$ CI) $=1.239(1.004-1.529)]$ with low-fat consumption".

The authors apologize for these errors.

\section{Publish your work in this journal}

Diabetes, Metabolic Syndrome and Obesity: Targets and Therapy is an international, peer-reviewed open-access journal committed to the rapid publication of the latest laboratory and clinical findings in the fields of diabetes, metabolic syndrome and obesity research. Original research, review, case reports, hypothesis formation, expert opinion and commentaries are all considered for publication. The manuscript management system is completely online and includes a very quick and fair peer-review system, which is all easy to use. Visit http://www.dovepress.com/testimonials.php to read real quotes from published authors. 